〔ウイルス 第 70 巻 第 1 号, pp.37-44, 2020]

\title{
特集＼cjkstart新型コロナウイルス感染症 (COVID-19)
}

\section{2. 新型コロナウイルス感染症（COVID-19）臨床}

\author{
忽 那 賢 志 \\ 国立国際医療研究センター 国際感染症センター
}

\begin{abstract}
新型コロナウイルス感染者（COVID-19）はSARS-CoV-2 による呼吸器感染症である. 発症から数 日〜 1 週間ほど上気道炎症状が続き，一部の患者では肺炎症状が悪化し重症化する．基礎疾患のある 患者および高齢者は重症化のリスクファクターである，鼻咽頭スワブまたは喀痰の PCR 検査で SARS-CoV-2 を検出することで診断する，治療は対症療法が主体となり，現時点ではレムデシビルの み臨床症状を短縮する有効性が示されている。感染対策は標準予防策に加え, 接触予防策, 飛沫予防 策を遵守し，エアロゾル発生手技を行う際には空気予防策を行う.
\end{abstract}

\section{臨床症状}

新型コロナウイルス感染症の潜伏期は 14 日以内であり， 多くの症例が曝露から概ね 5 日で発症する ${ }^{1,2)}$.

多くの有症状者で発熱, 呼吸器症状（咳嗽, 咽頭痛), 頭痛，倦怠感などの症状がみられる，鼻汁や鼻閉の頻度は 低いと考えられる ${ }^{2)}$. 下痢や嘔吐などの消化器症状の頻度 は多くの報告で 10\%未満であり SARS や MERS よりも少 ないと考えられる。臨床症状はインフルエンザや感冒に似 ているが，一部の患者で嗅覚異常・味覚異常を訴える患者 が存在する. Giacomelli らによれば, 88 人の COVID-19 患 者のうち問診可能であった 59 人を調査したところ，33.9\% に嗅覚または味覚障害のいずれかがあり，18.6\%は嗅覚障 害および味覚障害のいずれも認めたという3).インフルエ ンザ様症状に加えて, 嗅覚異常・味覚異常があれば, 新型 コロナウイルス感染症の可能性が高くなるかもしれない.

中国では発症から病院受診までの期間は約 5 日, 入院ま での期間は約 7 日と報告されており ${ }^{1)}$, 症例によっては発 症から 1 週間程度で重症化してくるものと考えられる。さ らに重症化する事例では 10 日目以降に集中治療室に入室 という経過を辿るようである ${ }^{4)}$ (図 1). 中国での 44672 人

連絡先

$\bar{\top} 162-8655$

東京都新宿区戸山 1-21-1

国立国際医療研究センター

TEL: 03-3202-7181

E-mail: skutsuna@hosp.ncgm.go.jp
のデータによると， $81 \%$ が軽症（肺炎がない，もしくは 軽度), $14 \%$ が重症 (呼吸困難, 低酸素血症, 24-48 時間 以内に肺炎像が肺面積の $50 \%$ 以上を占める), $5 \%$ が最重 症（呼吸不全, ショック, 多臟器不全) であった。このう ち $2.8 \%$ が死亡しており, 最重症の $5 \%$ のうち拈よそ半分 は救命可能と考えることができる.

重症化のリスクファクターとして, 高齢者, 基礎疾患（心 血管疾患, 心不全, 不整脈, 糖尿病, 悪性腫瘍, 慢性呼吸 器疾患, など）が知られている25).

40 代までは重症化は少なく, 50 代から年齢が高くなる に従って致命的も高くなっていく，中国での 44672 人の データからは 80 代の致命的は $14.8 \%$ にも登る ${ }^{2)}$ (図 2). また，基礎疾患のある患者でも基礎疾患のない患者と比べ て明らかに致命的が高い（図3).

妊婦での重症例はこれまでに報告はなく，先天性感染も 認められていない67)。臍带血や羊水，新生児からも

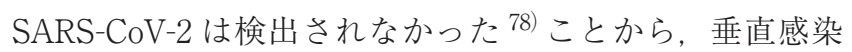
は起こらないのではないかと考えられている。 また乳児の 感染例においても重症例の報告はない9).

無症候性感染者も一定の割合で存在することが分かって いる. クルーズ船ダイアモンド・プリンセス号の乗客をス クリーニングで PCR 検査を行ったところ, 約 17\% が陽性 であり，そのうちおよそ半数が無症候性感染者であった ${ }^{10)}$.

胸部画像所見は, 両側抹消側の浸潤影・すりガラス影が 特徵的である（図4）。胸部 CT では肺炎像があっても, 胸部レントゲンでは肺炎と判断できない事例がある. 中国 での報告では胸部レントゲンでは $59.1 \%$ にしか肺炎像が 確認できなかったのに対し, 胸部 CTでは $86.2 \%$ で肺炎像 が確認できたという2). 撮影された対象が一部異なるため 


\section{新型コロナウイルス感染症の経過}

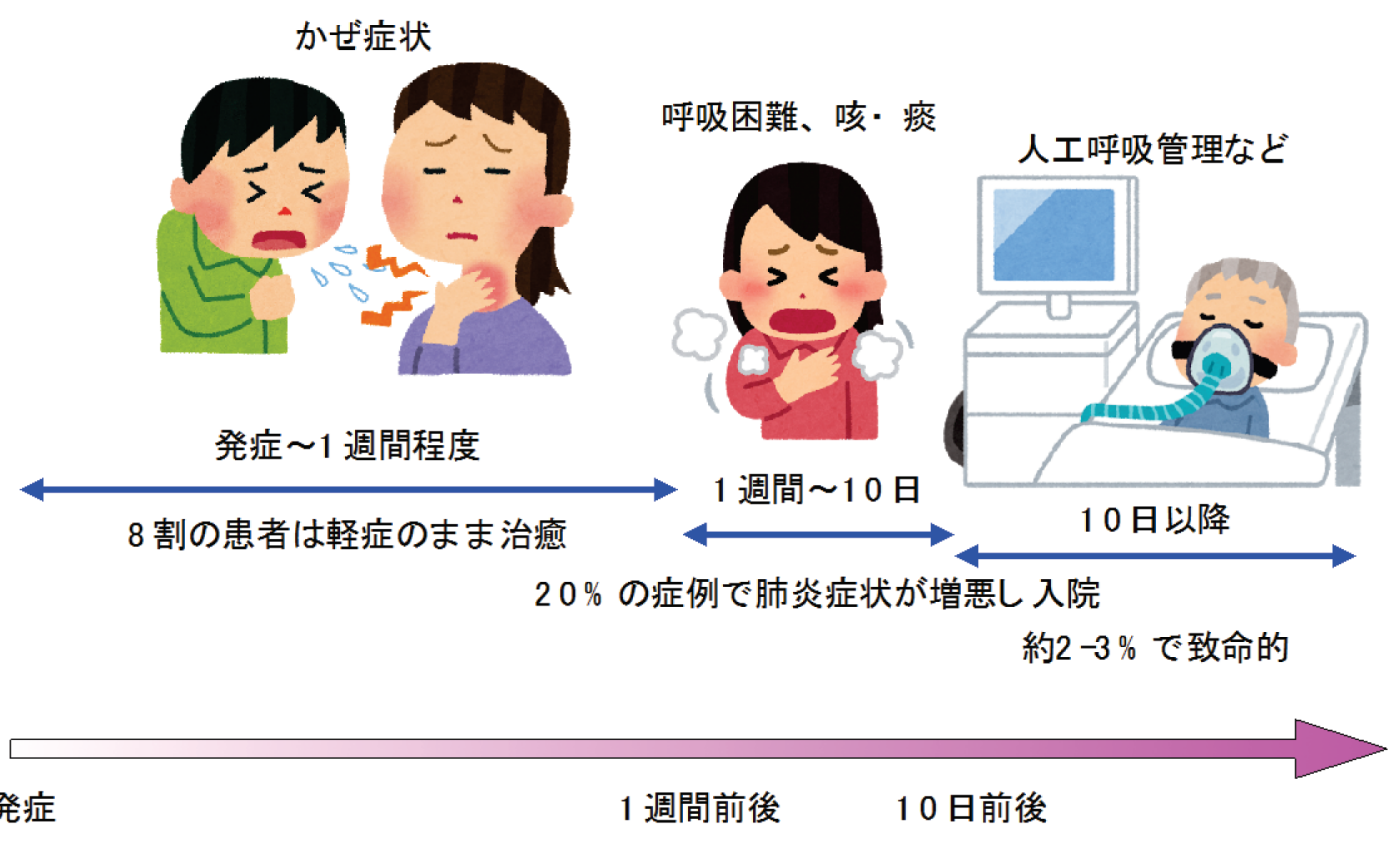

図 1 新型コロナウイルス感染症の典型的な経過

単純化はできないが，胸部レントゲンでは肺炎を 2-3 割は 見逃す可能性がある。接触歴があるなど検査前確率が高い 事例では胸部レントゲンで肺炎像を認めなくても胸部 CT を撮影することも検討すべきである，肺炎像は発症から経 過と共に広がっていくが, 無症候性感染者であっても胸部 CT を撮影すると肺炎像が観察されることがある ${ }^{11)}$. 全く 熱も呼吸器症状もない無症候性感染者であっても著明な肺 炎像が観察されることがあるのは本疾患の特徵と言える.

血液検査所見ではリンパ球低下がみられることがあり， 特に重症例では低い傾向にある2).

\section{検査・診断}

日本では PCR 検査で SARS-CoV-2 を検出することで診 断するのが一般的である.

2020 年 3 月 5 日までは行政検査として PCR 検査が行わ れていたが, 3 月 6 日からは SARS-CoV-2 の PCR 検査が 保険適用となり, 全国約 800 の医療機関の帰国者・接触者 外来において医師が新型コロナウイルス感染症を疑った場 合に算定できることとなった.

PCR 検査の検体については，2 月 27 日までは咽頭スワ ブまたは採取できれば喀痰が用いられてきた。しかし，咽 頭よりも鼻咽頭の方がウイルス量が多いことが明らかにな り 12)，現在は鼻咽頭スワブまたは喀痰が検体として推奨 されている (2019-nCoV (新型コロナウイルス) 感染を疑う 患者の 検体採取・輸送マニュアル〜2020/02/28 更新版〜 https://www.niid.go.jp/niid/images/pathol/pdf/2019nCoV_200228.pdf). WHOは初回の PCR 検査が院性であっ てもなお強く疑われる事例では, 繰り返し複数検体を採取 し検査を行うことを推奨している ${ }^{13)}$. 実際にCT所見では 新型コロナウイルス感染症が強く疑われるにもかかわらず 初回の PCR 検査が陰性であったが, 繰り返し検査するこ とで陽性が判明する事例も自験例を含め多く報告されてい る 14,15).

新型コロナウイルス感染症と確定診断されれば，5月時 点では感染症法での指定感染症に指定されているため, 原 則として感染症指定医療機関の感染症病床に入院すること になる。また診断した医師は速やかに保健所に届け出を行 わなければならない.

\section{治療}

CDC, WHO がそれぞれ治療指針を示しているが，基本は 適切な感染対策を行いながら支持療法を行うことである 16,17$)$. 中国での 1099 例の報告では症例の $58 \%$ に点滴抗菌薬, 35.8\% にオセルタミビル，2.8\% に抗真菌薬， $18.6 \%$ にグル ココルチコイドが投与されている ${ }^{2)}$. また $41.3 \%$ に酸素投 与が, $6.1 \%$ に人工呼吸管理（侵襲性 $2.3 \%$, 非侵襲性 $5.1 \%$ ), 0.8\% で腎代替療法が行われており，0.5\%で ECMO (extracorporeal membrane oxygenation)が使用されている. 全 体の 5\% が集中治療室に入室している.

1. 現時点で新型コロナウイルス感染症に有効性があると 


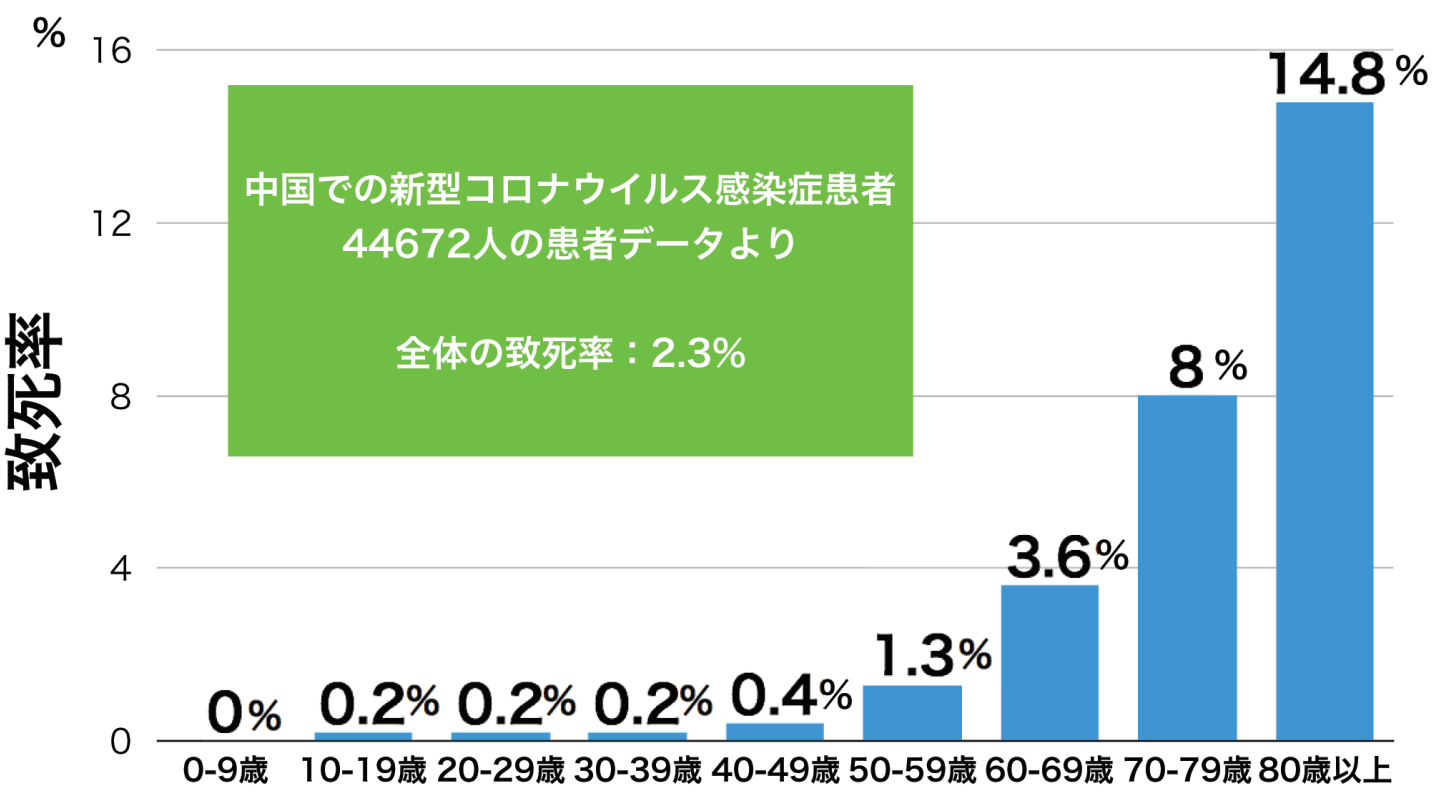

図 2 年齢別にみた新型コロナウイルス感染症の致死率 ${ }^{2)}$

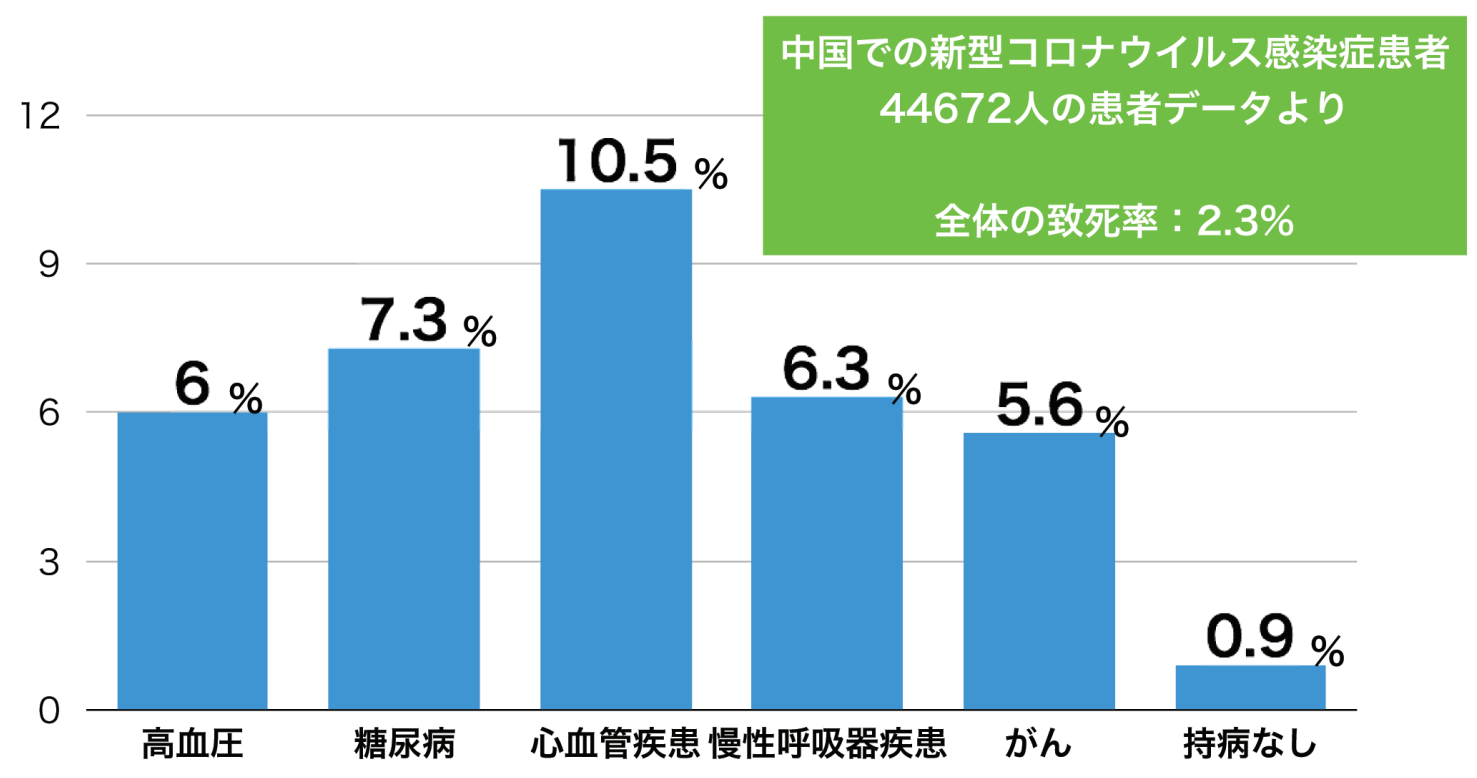

図 3 基礎疾患ごとにみた新型コロナウイルス感染症の致死率 2)

いえる治療薬はレムデシビルのみである. レムデシビ
ルエボラ出血熱の治療薬の候補としてこれまで他の
臨床試験で使用されていた薬剤である. 現在もコンゴ
民主共和国で流行が続いているエボラ出血熱の症例に
対して, ランダム化比較試験という形でレムデシビル
が投与されていた. しかし, 結果としてレムデシビル
はMAb114, REGN-EB3という2つの薬剤に治療効果
が劣ることが分かり, 現在はエボラ出血熱への投与は
中止されている 18). しかし, このレムデシビルが新型 コロナウイルス感染症に有効である可能性が示唆され ている。武漢ウイルス研究所がCell Research にレム デシビルの新型コロナウイルスに対する効果に関する 報告を発表している ${ }^{19)}$ ．培養細胞に新型コロナウイル スを感染させ，48 時間後のウイルス増殖の抑制効果を 見たところ，レムデシビルで高い阻害効果が観察され たという。また新型コロナウイルス感染症に対しても 


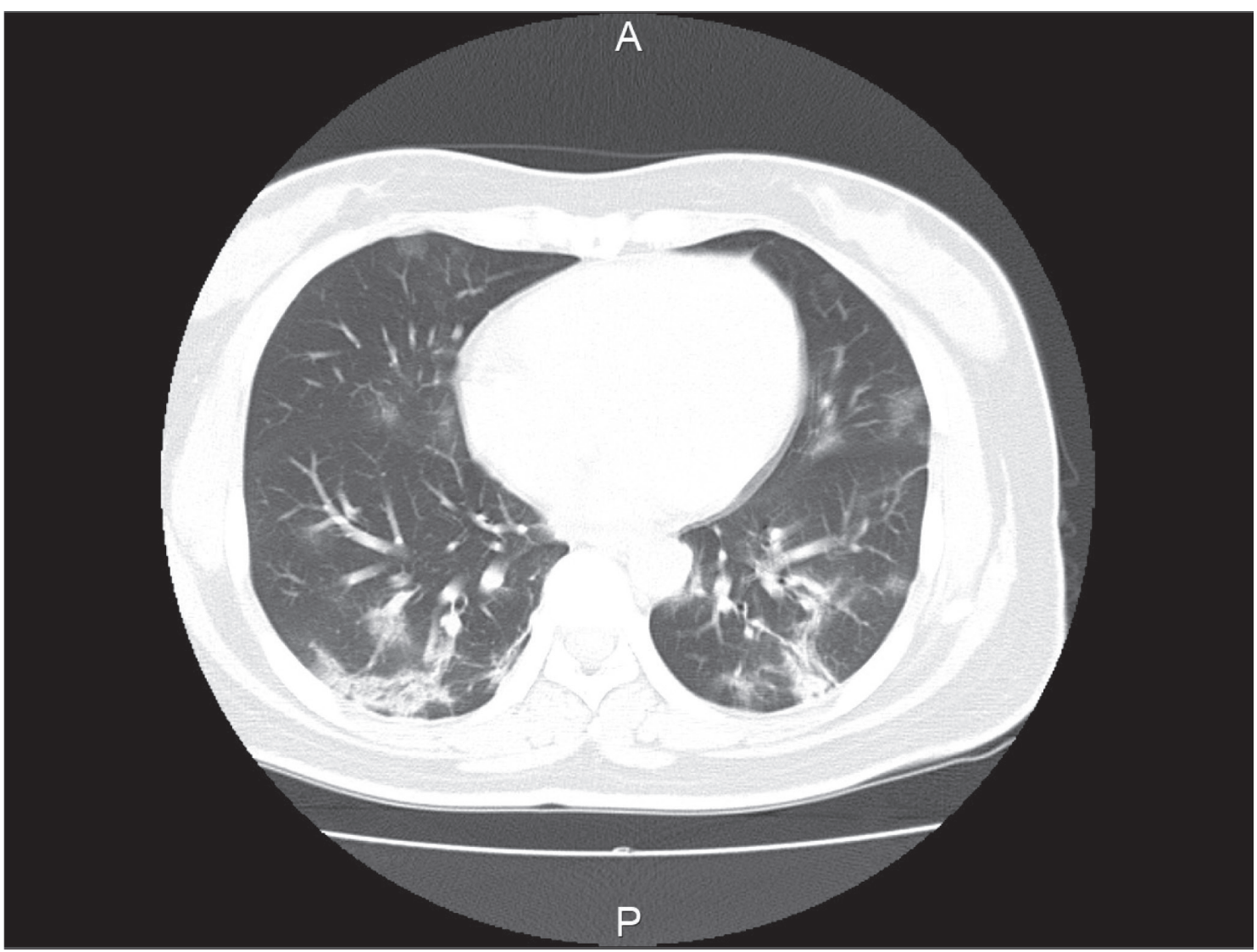

図 4 新型コロナウイルス感染症患者の胸部 CT 画像（自験例）

アメリカでの第 1 例および日本 · 欧米の重症例 53 例に compassionate use として投与されている 20,21). 中国で の 237 人の重症新型コロナウイルス感染症患者が登録 された RCT では死亡, 臨床的改善に有意差はなかった 22$)$ が，症例登録数が予定よりも少なかったためパワー不 足であった可能性が残る。一方，多国間医師主導治験 として実施され 1,063 人が登録された NIHの RCTでは, プラセボ群では臨床的改善に 15 日であったのに対しレ ムデシビル群では 11 日と $31 \%$ 短縮されたという速報 が発表されている（未論文化：NIH Clinical Trial Shows Remdesivir Accelerates Recovery from Advanced COVID-19 (April 29, 2020). https://www.niaid.nih.gov/newsevents/nih-clinical-trial-shows-remdesivir-acceleratesrecovery-advanced-covid-19)。2020 年 5 月 7 日に国内 で特例承認制度に基づき薬事承認された。

\section{感染対策}

医療従事者の感染を起こさないことは新型コロナウイル ス感染症の診療の上で最も大事なことの一つである。中国 の 138 例の報告では感染者の 43\% が病院内で感染した事 例と考えられている ${ }^{23)}$ ，その他のコロナウイルス感染症 である SARS や MERS も病院内感染症を起こしやすいこ
とが知られており 24,25)，病院という閉鎖空間で，特に患者 と近距離で接する機会の多い医療従事者はリスクとなる.

感染経路は接触感染および飛沫感染と考えられている が，エアロゾルが発生する状況では空気予防策が推奨され る。 WHO は標準予防策に加えて接触予防策，飛沫予防策 を行い，エアロゾル発生手技を行う際には空気予防策を行 うことを推奨している (WHO. Rational use of personal protective equipment for coronavirus disease 2019 (COVID19). https://apps.who.int/iris/bitstream/handle/10665/ 331215/WHO-2019-nCov-IPCPPE_use-2020.1-eng.pdf). 活 動ごとに推奨される個人防護具を表 1 に示す。CDC は常に空 気予防策を取る点以外は同様の推奨となっている (CDC. Interim Infection Prevention and Control Recommendations for Patients with Confirmed Coronavirus Disease 2019 (COVID-19) or Persons Under Investigation for COVID-19 in Healthcare Settings. https://www.cdc.gov/coronavirus/ 2019-ncov/infection-control/control-recommendations. html? CDC_AA_refVal= https $\% 3 \mathrm{~A} \% 2 \mathrm{~F} \% 2 \mathrm{~F}$ www.cdc. gov\%2Fcoronavirus\%2F2019-ncov\%2Fhcp\% 2Finfectioncontrol.html). どちらにも共通するのは，目の防護が強調 されておりアイガードの使用が推奨されている点である.

国立感染症研究所と国立国際医療研究センター国際感染 
表 1 対象者, 活動ごとに推奨される個人防護具 （WHO. Rational use of personal protective equipment for coronavirus disease 2019 (COVID-19). https://apps.who.int/iris/bitstream/handle/10665/331215/WHO-2019-nCov-IPCPPE_use-2020.1-eng.pdf)

\begin{tabular}{|c|c|c|c|}
\hline \multicolumn{4}{|l|}{ 入院患者 } \\
\hline \multirow{4}{*}{ 病室 } & \multirow{2}{*}{ 医療従事者 } & 診療を行う医療従事者 & $\begin{array}{l}\text { サージカルマスク, ガウン, 手袋, ゴーグルま } \\
\text { たはアイシールド }\end{array}$ \\
\hline & & エアロゾル発生手技 & $\begin{array}{l}\text { N95 マスク, ガウン, 手袋, ゴーグルまたはア } \\
\text { イシールド }\end{array}$ \\
\hline & 清掃者 & 患者の病室に入室時 & $\begin{array}{l}\text { サージカルマスク, ガウン，嬮手の手袋，ゴー } \\
\text { グルまたはアイシールド（飛沫のリスクがあれ } \\
\text { ば), ブーツ }\end{array}$ \\
\hline & 訪問者 & 患者の病室に入室時 & サージカルマスク, 手袋 \\
\hline $\begin{array}{l}\text { その他の患者が移動するエ } \\
\text { リア(病棟, 廊下など }) .\end{array}$ & 全てのスタッフ & 患者に接する以外の全ての活動 & 個人防護具は不要 \\
\hline \multirow{3}{*}{ トリアージ } & 医療従事者 & 直接の接触のないスクリーニング時 & $\begin{array}{l}\text { 1M 以上の距離を保つ } \\
\text { 個人防護具は不要 }\end{array}$ \\
\hline & 呼吸器症状を伴う患者 & 全ての場合 & $\begin{array}{l}\text { 1M 以上の距離を保つ } \\
\text { マスクを着用する }\end{array}$ \\
\hline & 呼吸器症状のない患者 & 全ての場合 & 個人防護具は不要 \\
\hline \multirow[t]{2}{*}{ 検査室 } & 検査技師 & 呼吸器検体操作時 & $\begin{array}{l}\text { サージカルマスク, ガウン，手袋，ゴーグルま } \\
\text { たはアイシールド (飛沫のリスクがあれば) }\end{array}$ \\
\hline & 対象者 & 活動 & 個人防護具 \\
\hline \multicolumn{4}{|l|}{ 外来患者 } \\
\hline \multirow{5}{*}{ 診察室 } & 医療従事者 & 呼吸器症状のある患者の診察 & サージカルマスク, ガウン, 手袋, 目の防護 \\
\hline & 医療従事者 & 呼吸器症状のない患者の診察 & 標準予防策 \\
\hline & 呼吸器症状のある患者 & 全ての場合 & サージカルマスクを装着 \\
\hline & 呼吸器症状のない患者 & 全ての場合 & 個人防護具は不要 \\
\hline & 清掃者 & $\begin{array}{l}\text { 呼吸器症状のある患者の診察後, 診察 } \\
\text { の合間 }\end{array}$ & $\begin{array}{l}\text { サージカルマスク, ガウン, 厚手の手袋, ゴー } \\
\text { グルまたはアイシールド（飛沫のリスクがあれ } \\
\text { ば), ブーツ }\end{array}$ \\
\hline \multirow[t]{2}{*}{ 待合室 } & 呼吸器症状のある患者 & 全ての場合 & $\begin{array}{l}\text { マスクを着用する。速やかに隔離室または他の } \\
\text { 患者から離れた場所に移動しももうてできな } \\
\text { い場合は他の患者から少なくとも } 1 \mathrm{~m} \text { の空間距 } \\
\text { 離を確保する }\end{array}$ \\
\hline & 呼吸器症状のない患者 & 全ての場合 & 個人防護具は不要 \\
\hline \multirow{3}{*}{ トリアージ } & 医療従事者 & 直接の接触のないスクリーニング時 & $\begin{array}{l}1 \mathrm{M} \text { 以上の距離を保つ } \\
\text { 個人防護具は不要 }\end{array}$ \\
\hline & 呼吸器症状のある患者 & 全ての場合 & $\begin{array}{l}1 \mathrm{M} \text { 以上の距離を保つ } \\
\text { 個人防護具は不要 }\end{array}$ \\
\hline & 呼吸器症状のない患者 & 全ての場合 & 個人防護具は不要 \\
\hline
\end{tabular}

症センターから示されている「新型コロナウイルス感染症 に対する感染管理」でも WHO と同様に,

\section{I 標準予防策に加え, 接触, 飛沫予防策を行う}

II 診察室および入院病床は個室が望ましい

III 診察室および入院病床は陰圧室である必要はないが,

\section{十分換気する}

IV エアロゾルが発生する可能性のある手技（例えば気道 吸引，気管内挿管，下気道検体採取）を実施する場合 には，N95 マスク（または DS2 など，それに準ずるマ スク), 眼の防護具（ゴーグルまたはフェイスシール
ド), 長袖ガウン, 手袋を装着する V 患者の移動は医 学的に必要な目的に限定する なお, 職員（受付, 案内係, 警備員など）も標準子防策を 遵守する.

と記載されている（国立感染症研究所, 国立国際医療研究 センター 国際感染症センター. 新型コロナウイルス感染症 に対する感染管理 改訂 2020 年 3 月 5 日.https://www. niid.go.jp/niid/images/epi/corona/2019nCoV-01-200305. pdf). 


\section{参考文献}

1) Li Q, Guan X, Wu P, et al. Early Transmission Dynamics in Wuhan, China, of Novel Coronavirus-Infected Pneumonia. The New England journal of medicine 2020.

2 ) Guan WJ, Ni ZY, Hu Y, et al. Clinical Characteristics of Coronavirus Disease 2019 in China. The New England journal of medicine 2020.

3 ) Giacomelli A, Pezzati L, Conti F, et al. Self-reported olfactory and taste disorders in SARS-CoV-2 patients: a cross-sectional study. Clinical infectious diseases : an official publication of the Infectious Diseases Society of America 2020.

4) Huang C, Wang Y, Li X, et al. Clinical features of patients infected with 2019 novel coronavirus in Wuhan, China. Lancet (London, England) 2020; 395 (10223): 497-506.

5 ) Liang W, Guan W, Chen R, et al. Cancer patients in SARS-CoV-2 infection: a nationwide analysis in China. The Lancet Oncology 2020; 21(3): 335-7.

6 ) Li Y, Zhao R, Zheng S, et al. Lack of Vertical Transmission of Severe Acute Respiratory Syndrome Coronavirus 2, China. Emerging infectious diseases 2020; 26(6).

7 ) Chen H, Guo J, Wang C, et al. Clinical characteristics and intrauterine vertical transmission potential of COVID-19 infection in nine pregnant women: a retrospective review of medical records. The Lancet 2020.

8 ) Wang X, Zhou Z, Zhang J, Zhu F, Tang Y, Shen X. A case of 2019 Novel Coronavirus in a pregnant woman with preterm delivery. Clinical infectious diseases : an official publication of the Infectious Diseases Society of America 2020.

9) Wei M, Yuan J, Liu Y, Fu T, Yu X, Zhang Z-J. Novel coronavirus infection in hospitalized infants under 1 year of age in China. Jama 2020.

10) Kakimoto K, Kamiya H, Yamagishi T, Matsui T, Suzuki $\mathrm{M}$, Wakita T. Initial Investigation of Transmission of COVID-19 Among Crew Members During Quarantine of a Cruise Ship - Yokohama, Japan, February 2020. MMWR Morbidity and mortality weekly report 2020; 69(11):312-3.

11) Shi H, Han X, Jiang N, et al. Radiological findings from 81 patients with COVID-19 pneumonia in Wuhan, China: a descriptive study. The Lancet Infectious diseases 2020.

12) Zou L, Ruan F, Huang M, et al. SARS-CoV-2 Viral Load in Upper Respiratory Specimens of Infected Patients.
The New England journal of medicine 2020.

13) Organization WH. Laboratory biosafety guidance related to coronavirus disease 2019 (COVID-19): interim guidance, 12 February 2020: World Health Organization, 2020.

14) Xie X, Zhong Z, Zhao W, Zheng C, Wang F, Liu J. Chest CT for Typical 2019-nCoV Pneumonia: Relationship to Negative RT-PCR Testing. Radiology 2020: 200343.

15) Wu J, Liu J, Zhao X, et al. Clinical Characteristics of Imported Cases of COVID-19 in Jiangsu Province: A Multicenter Descriptive Study. Clinical infectious diseases : an official publication of the Infectious Diseases Society of America 2020.

16) Control CfD, Prevention. Interim Clinical Guidance for Management of Patients with Confirmed 2019 Novel Coronavirus (2019-nCoV) Infection, Updated January 30, 2020.

17) Organization WH. Novel Coronavirus (2019-nCoV) technical guidance: Patient management.

18) Mulangu S, Dodd LE, Davey RT, Jr., et al. A Randomized, Controlled Trial of Ebola Virus Disease Therapeutics. The New England journal of medicine 2019; 381(24): 2293-303.

19) Wang M, Cao R, Zhang L, et al. Remdesivir and chloroquine effectively inhibit the recently emerged novel coronavirus (2019-nCoV) in vitro. Cell research 2020; 30(3): 269-71.

20) Holshue ML, DeBolt C, Lindquist S, et al. First Case of 2019 Novel Coronavirus in the United States. The New England journal of medicine 2020; 382(10): 929-36.

21) Grein J, Ohmagari N, Shin D, et al. Compassionate Use of Remdesivir for Patients with Severe Covid-19. The New England journal of medicine 2020.

22) Wang Y, Zhang D, Du G, et al. Remdesivir in adults with severe COVID-19: a randomised, double-blind, placebo-controlled, multicentre trial. Lancet (London, England) 2020; 395(10236): 1569-78.

23) Wang D, Hu B, Hu C, et al. Clinical Characteristics of 138 Hospitalized Patients With 2019 Novel Coronavirus-Infected Pneumonia in Wuhan, China. Jama 2020.

24) Cheng PK, Wong DA, Tong LK, et al. Viral shedding patterns of coronavirus in patients with probable severe acute respiratory syndrome. Lancet (London, England) 2004; 363(9422): 1699-700.

25) Oboho IK, Tomczyk SM, Al-Asmari AM, et al. 2014 MERS-CoV outbreak in Jeddah--a link to health care facilities. The New England journal of medicine 2015; 372(9): 846-54. 


\title{
COVID-19: From a clinician's perspective.
}

\author{
Satoshi KUTSUNA \\ Disease Control and Prevention Center, National Center for Global health and Medicine
}

Coronavirus disease 2019 (COVID-19) is a respiratory tract infection caused by SARS-CoV-2. As of March 30, 2020, there have been 693,224 reported patients with COVID-19 worldwide, with 1,446 in Japan. Currently, although aspects of the route of transmission are unclear, infection by contact and by inhaling droplets is considered to be the dominant transmission route. Inflammatory symptoms in the upper respiratory tract persist for several days to 1 week after onset, and in some patients symptoms of pneumonia worsen and become severe. The presence of underlying diseases and advanced age are risk factors for increased severity. Diagnosis is based on detection of SARS-CoV-2 by polymerase chain reaction (PCR) testing of nasopharyngeal swabs or sputum. Symptomatic management is the main treatment for this disease. Although the efficacy of several agents is currently being tested, at present there is no effective therapeutic agent. To prevent infection, in addition to standard preventive measures, measures that counteract infection by contact and droplet inhalation are important. In addition, if procedures that cause aerosolization of virus are used, then measures that prevent airborne infection should be implemented. 
